\title{
EFFECTS OF ORAL OXYTETRACYCLINE-DOSING ON THE DEVELOPMENT OF ANTIBIOTIC-RESISTANCE IN THE INTESTINAL BACTERIAL FLORA OF MONOSEX (ALL-MALE) NILE TILAPIA OREOCHROMIS NILOTICUS FRIES
}

\author{
A. ROY ${ }^{1}$, T. J. ABRAHAM ${ }^{1 *}$, J. SINGHA ${ }^{1}$ AND P. K. PATIL ${ }^{2}$ \\ ${ }^{1}$ Department of Aquatic Animal Health,West Bengal University of Animal and Fishery Sciences, \\ Kolkata-700 094, West Bengal, India \\ ${ }^{2}$ Aquatic Animal Health and Environment Division, ICAR-Central Institute of Brackishwater \\ Aquaculture, Raja Annamalai Puram, Chennai-600 028, Tamil Nadu, India
}

\begin{abstract}
Effect of oxytetracycline (OTC) on the intestinal bacterial load and development of antibiotic-resistance in monosex (allmale) Nile tilapia(Oreochromis niloticus) fries were investigated under laboratory condition. The Nile tilapia fries were fed with OTC-diets at $80(1 \mathrm{X})$ and $800 \mathrm{mg} / \mathrm{kg}$ biomass/day (10X) for 10 consecutive days and compared with control. The OTC-dosing at $1 \mathrm{X}$ and $10 \mathrm{X}$ levels caused $0.23 \%$ and $1.52 \%$ mortalities, respectively. The feed intake was reduced by $8.75 \%$ in $1 \mathrm{X}$ and $31.25 \%$ in $10 \mathrm{X}$ groups during the OTC-dosing period. The control, $1 \mathrm{X}$ and 10X-dosed fries had total plate counts (TPCs) in the range of $8.68 \pm 0.05$ to $9.72 \pm 0.02,8.86 \pm 0.08$ to $9.83 \pm 0.05$ and $8.56 \pm 0.11$ to $9.73 \pm 0.02 \log _{10}$ cfu/g of intestine, respectively. In the $1 \mathrm{X}$ and $10 \mathrm{X}$ groups, the proportion of OTC-resistant bacteria increased significantly to $0.02276 \%$ (22 folds) and $0.017439 \%$ (17 folds), respectively from $0.001004 \%$ of the TPCs on day 10 OTC-dosing. The proportion of chloramphenicol-resistant bacteria increased significantly from $0.000082 \%$ to $0.016053 \%$ (195 folds) and $0.006208 \%$ (75 folds) of the TPCs on day 10 OTC-dosing in the $1 \mathrm{X}$ and 10X groups, respectively. On day 42 post-OTCdosing, OTC-resistant bacteria were almost 37.50 and 16.90 folds higher in the $1 \mathrm{X}$ and $10 \mathrm{X}$ groups than the control; while the respective increases were 70 and 55 folds in chloramphenicol-resistant bacteria. The OTC-dosing also favoured crossresistance to chloramphenicol among the intestinal bacterial flora of Nile tilapia fries. The release of these resistant bacteria may act as a reservoir for the horizontal transmission of antimicrobial resistance gene determinants to the microflora of the aquaculture environment, which is a serious cause for concern.
\end{abstract}

Key words: Antibiotic-resistance, Cross-resistance, Intestinal microflora, Oreochromis niloticus, Oxytetracycline-dosing

\section{INTRODUCTION}

Aquaculture, the fastest-growing sector of the world food economy, is expanding into new directions, intensifying and diversifying. With the fast growth, this industry is facing complexity due to stress and diseases. Aquaculture industries rely on antibiotics for disease control. The situation becomes much worse when aqua-farmers use antibiotics incorporated into feed at sub-therapeutic doses as prophylactics or growth promoters rather than using as therapeutics (Hernandez, 2005;
Romero, et al., 2012; Watts et al., 2017). It was reported that majority of these antibiotics are not completely metabolized by the fish and discharged into the water body, thereby making aquaculture responsible for contaminating the environment (Burridge et al., 2010; Almeida et al., 2019). Husevåg et al. (1991) found that fish pathogens in the sediments with resistance to antibiotics previously used for their treatment. This raised concern on the use of antibiotics in aquaculture. Oxytetracycline 
(OTC) is a broad-spectrum antibiotic from tetracycline family that is low-cost as compared to other antibiotics and represents nearly onethird of the antibiotic consumption in animal production in the European Union (Almeida et al., 2019). The concern over such antibacterial substances has become so high that their residues are being considered as chemical hazards. Not only the unapproved chemicals and antibacterial substances but also the approved antibiotics fall within the category of chemical hazards (Huss et al., 2003). There are greater concerns related to the development of antibiotic resistance in fish bacteria from the use of antibiotics. Acquisition of multiple antibiotic resistance in the cultured fish have been documented by several authors (Romero et al., 2012; Watts et al., 2017; Abraham and Bardhan, 2019). Also, the resistance genes can be transferred to disease-causing bacteria, resulting in antibiotic-resistant bacterial infections (Watts et al., 2017).

Tilapias (Oreochromis spp.) are the most widely grown and intensively reared farmed fish worldwide (Jansen et al., 2018). Several Oreochromis spp. are susceptible to bacterial diseases and, as a result, the use of antibiotics and antimicrobial agents are common in tilapia aquaculture (El-Sayed, 2013). Oxytetracycline is one of the most widely used antibiotics to treat systemic bacterial infections of fish (Jerbi et al., 2011; USFWS, 2015). The antibioticdiets retain the fish healthy and work as a safeguard for disease incidences (Islam et al., 2014). The gut microbiome strongly influences fish health by assisting the development of the gut epithelium, providing essential nutrients and stimulating the innate immune system (Nayak, 2010). The recent studies on tilapia microbiomes have produced enough records on the effects of dietary supplementation and rearing conditions (Fan et al., 2015; Giatsis et al., 2015; Adeoye et al., 2016; Parata et al., 2020). The dietary supplementation of antibiotics is reportedly led to changes in bacterial loads, population and their composition in the intestine (Depaola et al., 1995; Mannan et al., 2020). Since oxytetracycline is the most commonly used antibiotics in the aquaculture sector (Hernandez, 2005; Romero et al., 2012), this study was aimed to clarify whether the therapeutic OTCdose and dosage determine the level of colonisation of OTC-resistant fish intestinal flora, the level of OTC susceptibility of gut microbiota and development of cross-resistance among the gut-bacterial flora. This research assessed the development of OTC-resistance and chloramphenicol-resistance among the intestinal bacterial flora of 10 days OTC-dosed monosex Nile tilapia fries at the therapeutic dose and 10 times the therapeutic dose of oxytetracycline during the dosing and postdosing periods.

\section{MATERIALS AND METHODS}

Experimental fish: The experimental fish monosex (all-male) Nile tilapia (Oreochromis niloticus) fries of size $3.52 \pm 0.25 \mathrm{~cm}$ and $0.64 \pm 0.06 \mathrm{~g}$ were procured from Naihati (Lat. $22.8895^{\circ} \mathrm{N}$, Long. $88.4220^{\circ} \mathrm{E}$ ), North 24 Parganas district, West Bengal. The fries (1000 nos.) were packed in an oxygen-filled plastic bag with 3-L of well-aerated water and transported to the laboratory within $3 \mathrm{~h}$ of packing. On reaching the laboratory, the fries were acclimatized for $6 \mathrm{~h}$ in FRP tanks of 500-L capacity to reduce the transport stress. The fries were then released into the FRP tanks containing 400-L bore-well water at 500 fries/tank for further acclimatization for 15 days with continuous aeration. The fries were fed with commercial pellet feed of $1 \mathrm{~mm}$ size at $6 \%$ body weight (BW)/day thrice daily. About $50 \%$ of water was exchanged twice in a week.

Experimental design and set up: The experiments were carried out in the wet laboratory of the Faculty of Fishery Sciences, 
Chakgaria, Kolkata, India (Lat. $22^{\circ} 82^{\prime} \mathrm{N}$; Long. $88^{\circ} 20^{\prime}$ E) in 9 circular FRP tanks of 500-L capacity containing $300-\mathrm{L}$ of water using the acclimatized stocks of $O$. niloticus fries $(0.69 \pm 0.02 \mathrm{~g})$. Each tank was stocked with 220 fries. The experimental fishes were categorized into three groups, viz, group 1 (0X: control),

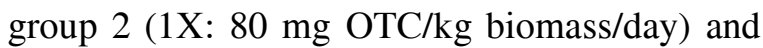
group 3 (10X: $800 \mathrm{mg}$ OTC/kg biomass/day), in triplicate. The experimental fish fries were grown in an ideal rearing water quality conditions, i.e, temperature $(25.82 \pm 0.96$ to $\left.29.12 \pm 1.25^{\circ} \mathrm{C}\right)$, dissolved oxygen $(4.23 \pm 0.10$ to $4.41 \pm 0.14 \mathrm{mg} / \mathrm{L}), \mathrm{pH} 7.88 \pm 0.05$ to $7.89 \pm 0.05$, nitrate $(0.13 \pm 0.01$ to $0.17 \pm 0.05$ $\mathrm{mg} / \mathrm{L})$, nitrite $(0.53 \pm 0.03$ to $0.55 \pm 0.03 \mathrm{mg} / \mathrm{L})$ and ammonia $(0.018 \pm 0.003$ to $0.019 \pm 0.005$ $\mathrm{mg} / \mathrm{L})$ throughout the experiment.

\section{Oxytetracycline (OTC) medicated diets} preparation: The therapeutic dose of OTC is $55-83 \mathrm{mg} / \mathrm{kg}$ biomass/day for 10 consecutive days (USFWS, 2015). Medicated OTC-diets were freshly prepared one week before the dosing period. The incorporation rate of OTC was calculated to deliver an approximate dosage of $0 \mathrm{mg}, 80 \mathrm{mg}$ and $800 \mathrm{mg}$ OTC/kg biomass/day for 10 consecutive days. The control and OTCdiets were prepared by top-coating the commercial feed with appropriate amounts of OTC in $5 \mathrm{~mL}$ vegetable oil separately as described in Julinta et al. (2019) to administer doses of 0,80 and $800 \mathrm{mg} / \mathrm{kg}$ biomass/day when fed at $6 \% \mathrm{BW} /$ day. The control diet was prepared without medication but coated with vegetable oil to minimize variation between the feeds. The feeds were properly mixed, air-dried overnight and placed into plastic sealable containers.

Oral oxytetracycline-dosing: The fries of $0 \mathrm{X}$ group were fed with control feed throughout the experimental period. During the pre-dosing period (day 1-7), the fries of groups $1 \mathrm{X}$ and 10X were fed with control feed. The $1 \mathrm{X}$ and 10X groups were fed with respective OTC-feeds at $6 \%$ BW thrice daily to achieve a concentration of $80 \mathrm{mg} / \mathrm{kg}$ biomass/day and $800 \mathrm{mg} / \mathrm{kg}$ biomass/day, respectively for 10 consecutive days from day 8 to 17 (i.e. dosing period). During the post-dosing period of 42 days (day 18-59), the fries of all groups were fed with control feed. Observations on mortality and feeding behaviour were recorded daily.

Bacteriological analysis: Analytical grade oxytetracycline dihydrate (HiMedia, India) and chloramphenicol powder (HiMedia, India) were used to supplement the agar plates. A stock antibiotic solution was prepared by dissolving the required concentration of OTC in sterile physiological saline solution. Chloramphenicol was first dissolved in $2 \mathrm{~mL}$ of absolute alcohol and made up to $20 \mathrm{~mL}$ using sterile distilled water. The Mueller Hinton agar (MHA: HiMedia, India) plates supplemented with OTC $(25 \mu \mathrm{g} / \mathrm{mL}$ agar medium) and chloramphenicol $(30 \mu \mathrm{L} / \mathrm{mL}$ agar medium) were prepared separately by mixing calculated volumes of the respective antibiotic stock solutions with tempered agar before pouring into the Petri plates. Control plates were prepared without antibiotic supplementation. The bacterial groups, viz., total plate counts (TPCs), oxytetracycline-resistant bacterial counts (ORBCs) and chloramphenicol-resistant bacterial counts (CRBCs) were enumerated following the spread plate technique (APHA, 1992).

For the enumeration of OTC-resistant and chloramphenicol-resistant bacteria, samples were collected from the 0X, 1X and 10X OTC-dosed groups. Ten fries from each tank of the respective groups were collected on day 0 , day 1 and day 10 OTC-dosing, and day 10, 20, 30 and 42 postOTC-dosing periods. The selected fries from each tank were euthanized using clove oil $(25 \mu \mathrm{L} / \mathrm{L})$, disinfected the skin surface by swabbing with $70 \%$ ethanol and dissected aseptically. The intestinal samples from 10 fries of each tank were collected aseptically using sterile forceps and transferred 
to a pre-weighed sterile test tube containing $10 \mathrm{~mL}$ of physiological saline solution $(0.85 \%$ $\mathrm{NaCl}$ ) and weighed again to get the weight of intestine. The contents were transferred to a previously sterilized mortar and homogenized using a pestle aseptically. Serial tenfold dilutions of intestinal contents were prepared in sterile saline and aliquots $(0.1 \mathrm{~mL}$ each) of appropriately diluted intestinal samples were spread uniformly on to the respective MHA plates, in triplicate. The plates were incubated at $30^{\circ} \mathrm{C}$ for $2-5$ days and the plates having 50-250 colonies were considered to calculate bacterial populations and expressed as colony-forming units (cfu). Each count was the mean value of viable colonies appearing in replicate agar plates made from an individual sample.

Statistical analysis: Bacterial counts were transformed to $\log _{10}$ counts/g intestine. Statistical differences in percentage estimates of ORBC and CRBC among the dosed groups on different dosing days were analyzed by one way ANOVA using Statistical Package for Social Sciences (IBM-SPSS) Version: 22.0 , considering a probability level of $\mathrm{P}<0.05$.

\section{RESULTS}

Mortalities and feed intake in oxytetracycline-dosed fish: The $1 \mathrm{X}$ and $10 \mathrm{X}$ OTC-dosing caused $0.23 \%$ and $1.52 \%$ mortalities during the experimental period. No mortalities were noted in the control group. The feed intake was reduced by $8.75 \%$ in $1 \mathrm{X}$ and $31.25 \%$ in $10 \mathrm{X}$ groups during the 10 days dosing period. Upon withdrawal of OTCdosing, an improvement in the feed intake was noticed in all treatment groups. The reduced feed intake during the post-dosing period was $0.50 \%$ in $1 \mathrm{X}$ and $4.75 \%$ in $10 \mathrm{X}$ groups.

Bacterial counts: The results of the TPCs, ORBCs and CRBCs in control and OTC-dosed Nile tilapia fry intestines as $\log _{10} \mathrm{cfu} / \mathrm{g}$ are shown in Figs. 1A-1C. At the start of the feeding experiment, the mean TPCs in the intestines of $0 \mathrm{X}, 1 \mathrm{X}$ and $10 \mathrm{X}$ groups were in the range of $9.72 \pm 0.01$ to $9.73 \pm 0.02 \log _{10}$ cfu/g. During the experimental period, the levels of TPCs decreased from $9.72 \pm 0.01$ to $8.68 \pm 0.02 \log _{10}$ $\mathrm{cfu} / \mathrm{g}$ in $0 \mathrm{X}$ group, although with some fluctuations. The ORBCs and CRBCs were fluctuating from $3.18 \pm 0.02$ to $4.73 \pm 0.02$ and $3.08 \pm 0.02$ to $4.21 \pm 0.01 \quad \log _{10} \mathrm{cfu} / \mathrm{g}$, respectively (Fig. 1A). Similarly, the TPCs were fluctuating from $8.86 \pm 0.03$ to $9.84 \pm 0.02 \log _{10}$ $\mathrm{cfu} / \mathrm{g}$ in $1 \mathrm{X}$-dosed fries. The levels of ORBCs increased from $4.96 \pm 0.03$ to $5.72 \pm 0.03 \log _{10}$ $\mathrm{cfu} / \mathrm{g}$ on day $10 \mathrm{OTC}-$ dosing and then to $5.83 \pm 0.03 \log _{10} \mathrm{cfu} / \mathrm{g}$ on day 10 post-OTCdosing. The ORBCs decreased gradually to $4.96 \pm 0.02 \log _{10} \mathrm{cfu} / \mathrm{g}$ at the end of the experiment. The CRBCs followed a similar trend, which increased from $3.65 \pm 0.03$ to $5.68 \pm 05 \log _{10}$ cfu/g on day 10 post-OTC-dosing and then decreased gradually to $4.62 \pm 0.07 \log _{10}$ $\mathrm{cfu} / \mathrm{g}$ at the end of the experiment (Fig. 1B). In 10X-dosed Nile tilapia fry intestine also, the TPCs were recorded a decreasing trend from $9.73 \pm 0.02$ to $8.56 \pm 0.05 \log _{10}$ cfu/g. The levels of ORBCs and CRBCs were $4.73 \pm 0.02$ and $3.65 \pm 0.0 .03 \log _{10} \mathrm{cfu} / \mathrm{g}$ during the pre-dosing period, which increased to $5.08 \pm 0.02$ and $5.05 \pm 0.042 \log _{10} \mathrm{cfu} / \mathrm{g}$ on day 1 OTC-dosing, respectively. The levels of ORBCs increased slightly to $5.94 \pm 0.03 \log _{10} \mathrm{cfu} / \mathrm{g}$; while the CRBCs increased to $5.49 \pm 0.02 \log _{10} \mathrm{cfu} / \mathrm{g}$ on day 10 OTC-dosing. During the post-OTCdosing period, the levels of ORBCs and CRBCs reduced to $4.33 \pm 0.03$ and $4.19 \pm 0.08 \log _{10}$ $\mathrm{cfu} / \mathrm{g}$, respectively on day 42 post-OTC-dosing (Fig. 1C).

The data on the proportion of ORBCs and CRBCs in the TPCs are presented in Figs. 2 and 3 , respectively. In $0 \mathrm{X}$ group the proportion ORBCs was $0.001004 \%$ of the TPCs initially, which fluctuated during the culture period and reduced significantly $(\mathrm{P}<0.05)$ to $0.00034 \%$ at the end of the experiment (Fig. 2). In the $1 \mathrm{X}$ group, 

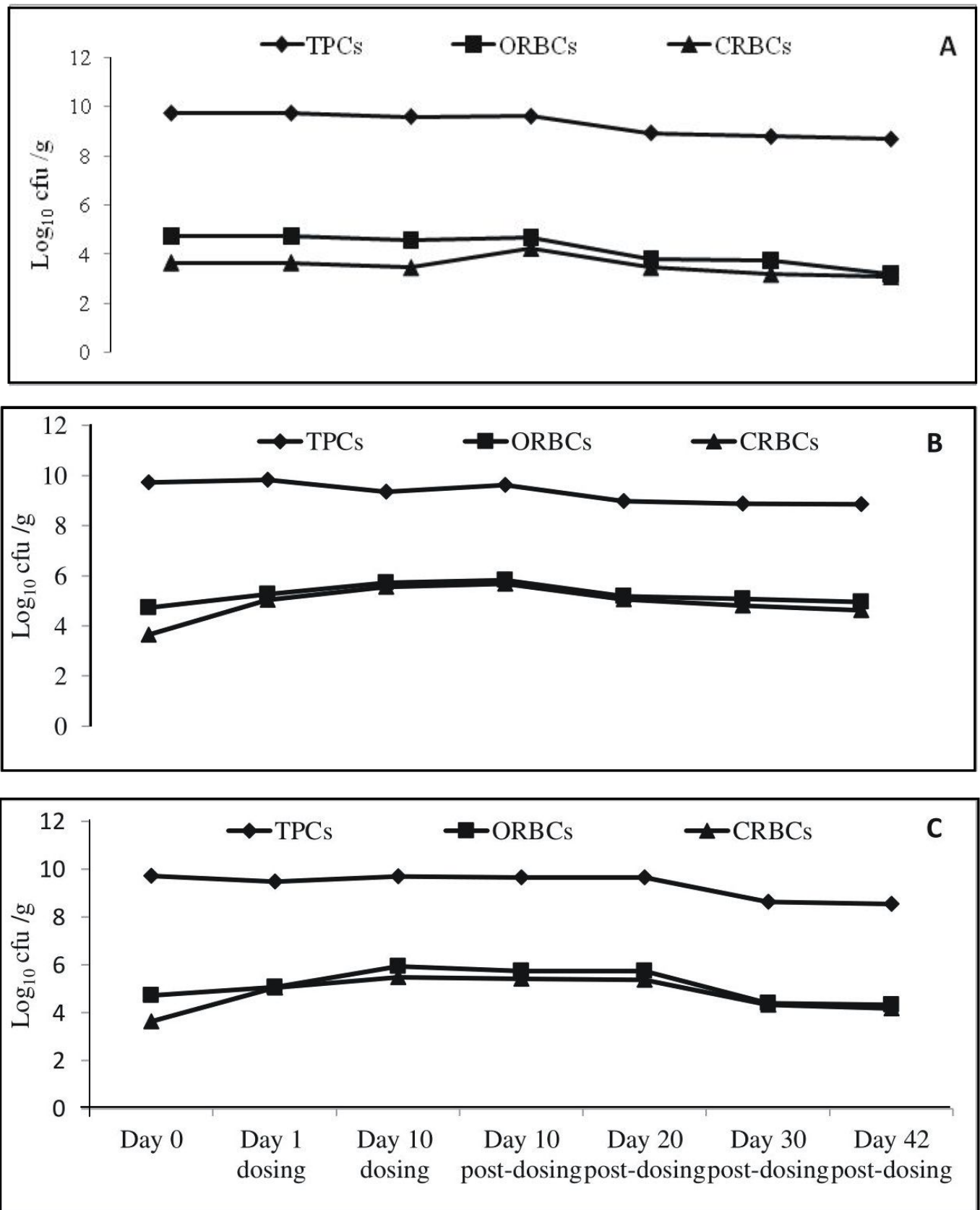

Fig. 1. Log total plate counts (TPCs), oxytetracycline-resistant bacterial counts (ORBCs) and chloramphenicol-resistant bacterial counts (CRBCs) in the gut of monosex Oreochromis niloticus fries fed with the (A) control feed (B) $1 \mathrm{X}$ feed and (C) 10X feed for 10 consecutive days $[\mathrm{X}=80 \mathrm{mg} / \mathrm{kg}$ biomass/day $]$

the proportion of ORBCs increased significantly to $0.02276 \%$ on day 10 OTCdosing $(\mathrm{P}<0.05)$, which then reduced significantly to $0.012759 \%$ of the TPCs on day 42 post-OTC-dosing $(\mathrm{P}<0.05)$. In the $10 \mathrm{X}$ group, the proportion of ORBCs increased significantly $(\mathrm{P}<0.05)$ from $0.001004 \%$ to the highest level of $0.017439 \%$ of the TPCs on day 10 OTC-dosing and then reduced significantly $(\mathrm{P}<0.05)$ to $0.005745 \%$ on day 
42 post-OTC-dosing. There existed significant differences $(\mathrm{P}<0.05)$ in ORBCs among the dosing groups and dosing periods (Fig. 2).

The proportions of CRBCs were comparatively lower than the CRBCs in all groups. During the pre-dosing period, the proportion of CRBCs was $0.000082 \%$ of the TPCs in all groups. In the control group, the proportions of CRBCs fluctuated from $0.000072-0.0004035 \%$ of the TPCs throughout the experiment. In the $1 \mathrm{X}$ group, the proportion of CRBCs increased significantly from $0.000082 \%$ to the highest level of $0.016053 \%$ on day 10 OTC-dosing $(\mathrm{P}<0.05)$, which then reduced significantly to $0.005746 \%$ of the TPCs on day 42 post-OTC-dosing $(\mathrm{P}<0.05)$. In the 10X group, CRBCs increased significantly from $0.000082 \%$ to the highest level of $0.006208 \%$ on day 10 OTC-dosing $(\mathrm{P}<0.05)$, which then reduced significantly to $0.004514 \%$ of the TPCs on day 42 post-OTC-dosing $(\mathrm{P}<0.05)$. There existed significant differences $(\mathrm{P}<0.05)$ in $\mathrm{CRBCs}$ among the dosing groups and dosing periods (Fig. 3).

The pooled data on the proportions of ORBCs and CRBCs in the TPCs are presented in Fig. 4. The control groups had $0.000878 \%$ and $0.000206 \%$ of ORBCs and CRBCs, respectively in the TPCs. The $1 \mathrm{X}$ groups had significantly $(\mathrm{P}<0.05)$ higher proportions of ORBCs $(0.012449 \%)$ and CRBCs $(0.007947 \%)$. The 10X group had slightly lower proportions of ORBCs $(0.008453 \% ; \mathrm{P}<0.05)$ and CRBCs $(0.004383 \% ; \mathrm{P}<0.05)$ than the $1 \mathrm{X}$ group. The significant $(p<0.05)$ differences in the proportions of ORBCs and CRBCs among the treatment groups were existed.

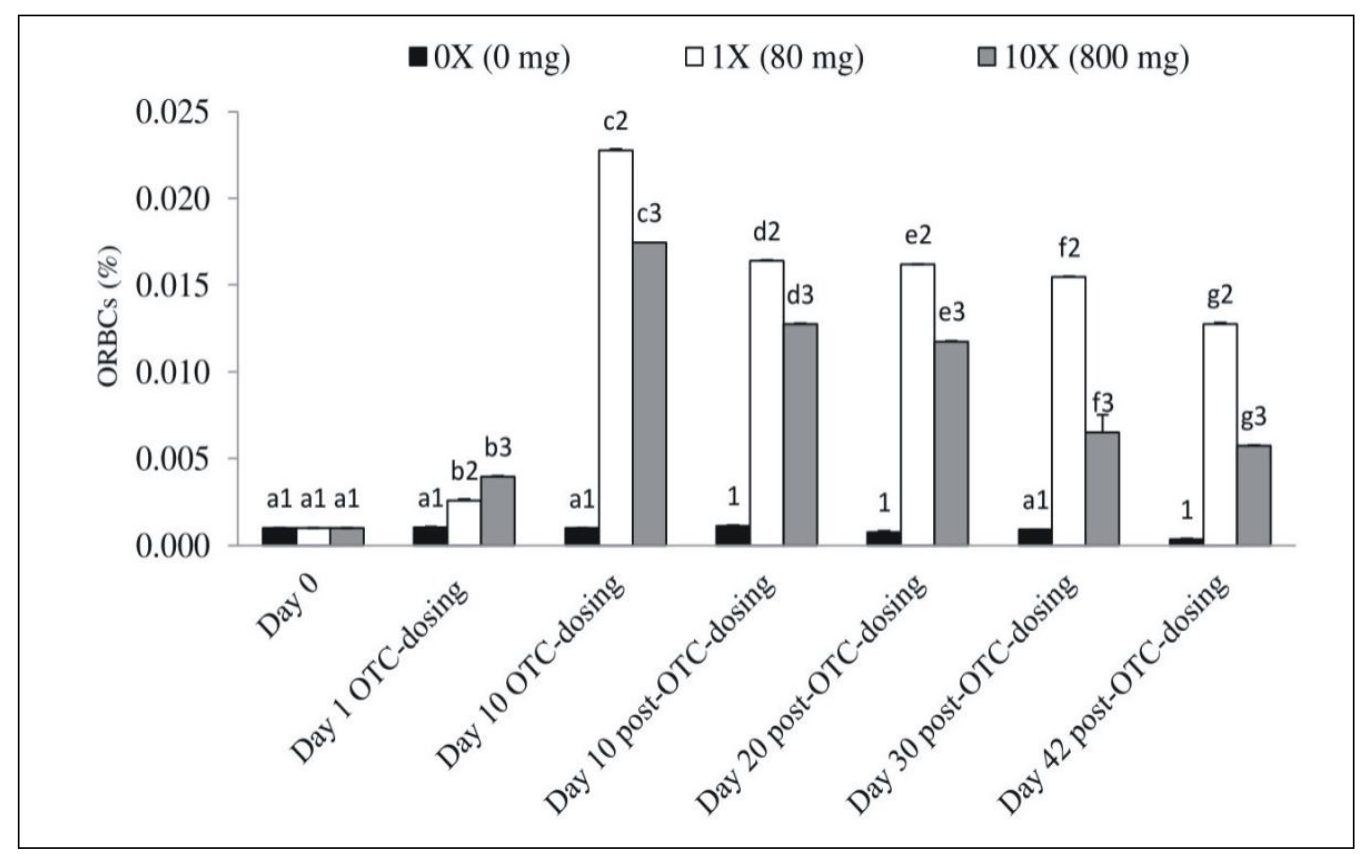

[1-3: Bars sharing common numerical for a particular dosing day differed insignificantly ( $\mathrm{P}>0.05)$. a-g: Bars sharing common alphabet for a particular treatment (dose) differed insignificantly $(\mathrm{P}>0.05)]$

Fig. 2. Proportion of oxytetracycline-resistant bacteria (ORBCs) in the gut total plate counts (TPCs) of oxytetracycline-dosed monosex Oreochromis niloticus fries at 0, 1 and 10 times the therapeutic dose $(80 \mathrm{mg} / \mathrm{kg}$ biomass/day) for 10 consecutive days 


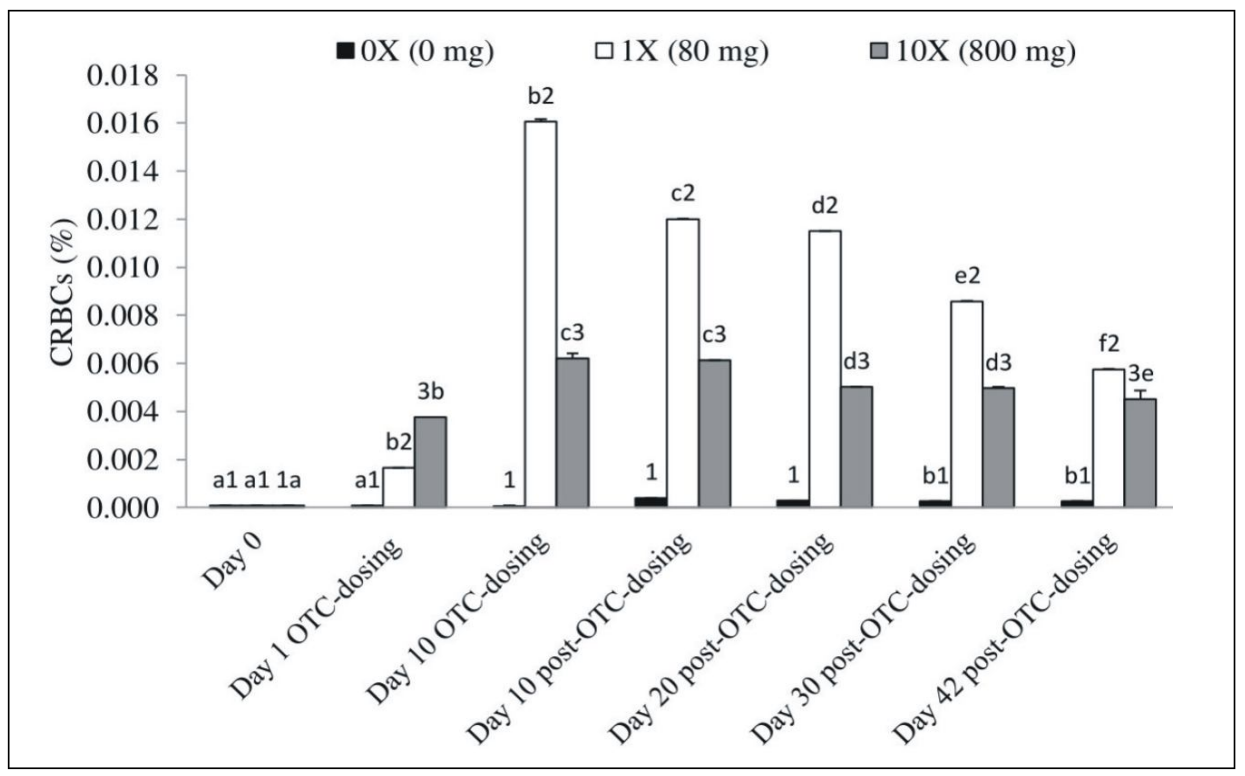

[1-3: Bars sharing common numerical for a particular dosing day differed insignificantly $(\mathrm{P}>0.05)$. a-f: Bars sharing common alphabet for a particular treatment (dose) differed insignificantly ( $P>0.05)]$

Fig. 3. Proportion of chloramphenicol-resistant bacteria (CRBCs) in the gut total plate counts (TPCs) of oxytetracycline-dosed monosex Oreochromis niloticus fries at 0,1 and 10 times the therapeutic dose $(80 \mathrm{mg} / \mathrm{kg}$ biomass/day) for 10 consecutive days

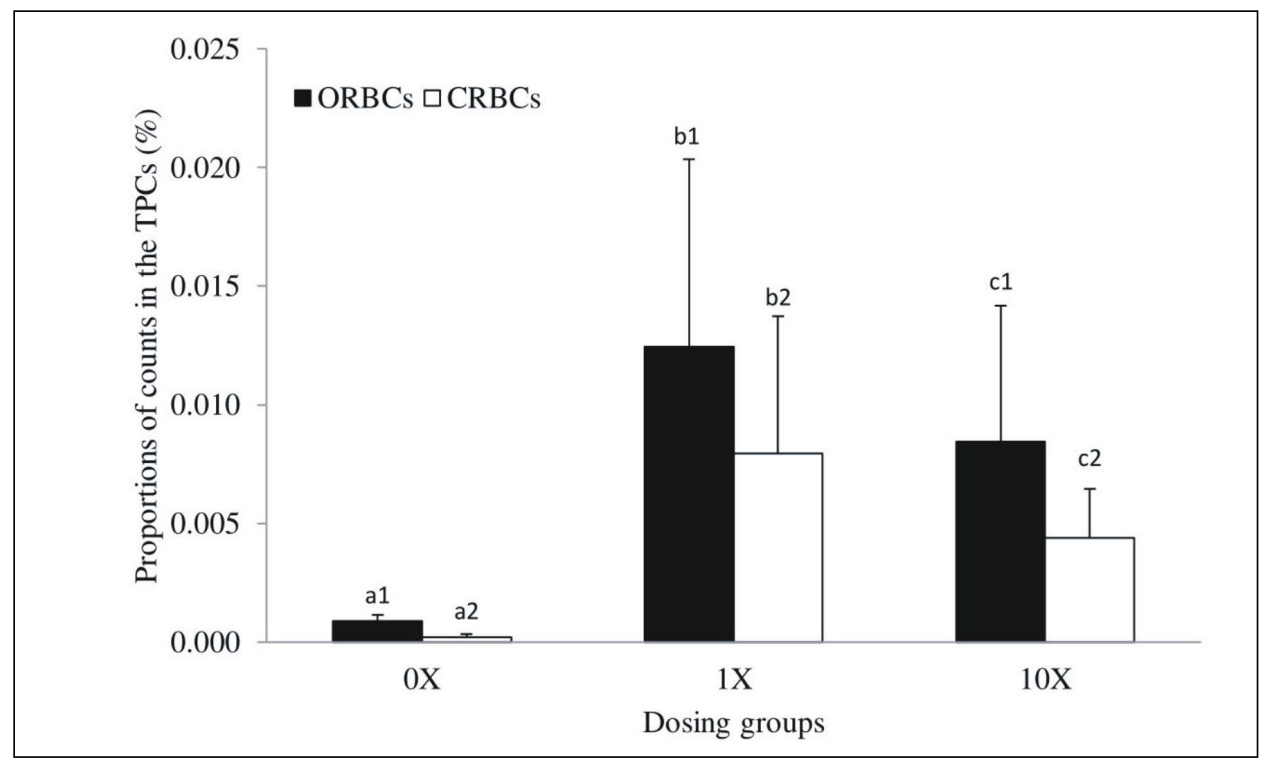

[Each data represent the pooled observations of the respective treatment. 1-2: Bars sharing common numerical for a particular treatment (dose) differed insignificantly $(\mathrm{P}<0.05)$. a-c: Bars sharing common alphabet for a particular group of bacterial counts (ORBCs or CRBCs) differed insignificantly $(\mathrm{P}>0.05)]$

Fig. 4. Proportion of oxytetracycline-resistant bacteria (ORBC) and chloramphenicol-resistant bacteria (CRBC) in the gut total plate counts of oxytetracycline-dosed monosex Oreochromis niloticus fries at 0,1 and 10 times the therapeutic dose $(80 \mathrm{mg} / \mathrm{kg}$ biomass/ day) for 10 consecutive days 


\section{DISCUSSION}

The experimental fish fries were grown in ideal conditions in the wet laboratory as indicated by the water quality parameters, which did not vary much and exerted no stress to the fries. Except for the mortalities and reduced feed intake in OTC-dosed groups during the dosing period, no abnormalities were noted in the fries. The observations on the mortalities and reduced feed intake in a dose-dependent manner indicated that the fries were stressed during the OTC-dosing. The results corroborate the observations of Julinta et al. (2019) recorded in Nile tilapia. The intestinal microflora is greatly influenced by the feed ingested, which sometimes contain various chemical and drugs and, therefore, an understanding of how antibacterial compounds modify the gastrointestinal microbiota of farmed fish could help to improve aquaculture management to reduce antibiotic use and enhance the safety of farmed fish. It is, therefore, important to determine the dynamics of gut microbial flora as an effect of antibiotics in fish diet. It has been reported that antibiotic-resistance has become a serious issue in various environments and human health concern (Watts et al., 2017). Recently, several studies have looked at what factors shape and modulate the development of the tilapia gut microbiome (Giatsis et al., 2014, 2015; Parata et al., 2020). As seen in Fig. 1, the initial mean TPCs $\left(9.73 \pm 0.02 \log _{10}\right.$ $\mathrm{cfu} / \mathrm{g}$ ) in the intestines of all fry groups indicated that the fries were well fed with a healthy microbiome. During the experimental period, the levels of TPCs decreased to $8.68 \pm 0.02 \log _{10}$ $\mathrm{cfu} / \mathrm{g}$ in the control group and $8.86 \pm 0.03$ to $8.56 \pm 0.05 \log _{10} \mathrm{cfu} / \mathrm{g}$ in OTC dosed groups, although with fluctuations. On the other hand, Mannan et al. (2020) recorded higher bacterial counts in the gut of Nile tilapia as $1.61 \pm 2.25 \times 10^{10} \mathrm{cfu} / \mathrm{g}$ in control and, $1.61 \pm 1.25 \times 10^{10}$ and $1.11 \pm 1.25 \times 10^{10} \mathrm{cfu} / \mathrm{g}$ in OTC-treated groups. In contrast, the TPCs lower than the present study were also documented. For example, Uddin and Ai-Harbi (2004) reported TPCs in the range of $3.40 \pm 1.80 \times 10^{6}$ to $5.80 \pm 0.40 \times 10^{7} \log _{10} \mathrm{cfu} / \mathrm{g}$ in tilapia intestine; while Mandal et al. (2009) reported a mean TPCs of $8.81 \pm 0.45 \times 10^{5} \log _{10}$ $\mathrm{cfu} / \mathrm{g}$ in the intestine of pond reared Nile tilapia. The higher TPCs in the intestines of Nile tilapia fries could be attributed to high feeding under the controlled condition as the fries were fed with pellet feed at $6 \% \mathrm{BW}$ or related to differences in environmental conditions.

The intestinal TPCs of Nile tilapia recorded on day 10 OTC-dosing did not vary much in terms of load, i.e., $9.58 \pm 0.01,9.35 \pm 0.02$ and $9.70 \pm 0.03 \log _{10} \mathrm{cfu} / \mathrm{g}$ in $0 \mathrm{X}, 1 \mathrm{X}$ and $10 \mathrm{X}$ groups, respectively. The bacterial loads in Nile tilapia intestine at the start of OTC medication reported in the present study were more or less similar to those reported by others observed for different fish (DePaola et al., 1995; Chowdhury et al., 1989; Mannan et al., 2020). In a study Mannan et al. (2020) observed about 2 log units reduction in the intestine bacterial loads of Nile tilapia from $1.81 \pm 1.25 \times 10^{10}$ to $3.06 \pm 2.08 \times 10^{8}$ $\mathrm{cfu} / \mathrm{g}$ in 7 days of oral OTC-treatment. In 30 days, intestinal bacterial loads reduced by about $3 \log$ units to $3.45 \pm 4.46 \times 10^{7} \mathrm{cfu} / \mathrm{g}$. In the $1 \mathrm{X}$ group, the levels of TPCs were reduced slightly on day 10 OTC-dosing and fluctuated thereafter. While in the $10 \mathrm{X}$ group, the TPCs remained constant till day 20 post-OTC-dosing and reduced slightly thereafter. The results of the present study suggested that the OTCdosing for 10 days had no significant effect on the levels of intestinal TPCs of Nile tilapia fries.

Oxytetracycline-resistant bacteria: Though the OTC is a widely used antibacterial agent, the awareness of its use, efficacy and the environmental impact are inadequate among farmers. The ORBCs of the control group fluctuated from $3.18 \pm 0.02$ to $4.75 \pm 0.02 \log _{10}$ $\mathrm{cfu} / \mathrm{g}$, which indicated that considerable numbers of intestinal bacterial populations were 
resistant to OTC. The results on the proportion of ORBCs in the TPCs indicated that about 0.00034 to $0.00112 \%$ of the intestinal flora of the monosex Nile tilapia fries were resistant to OTC. These results indicated that the fries may harbour OTC-resistant bacteria as normal flora, acquiring from the feed and rearing water. In catfish feed samples, the antibiotic-resistance frequencies were reportedly ranging from 7 to $65 \%$ (DePaola et al., 1995). Some nonmedicated feed for fish contained considerable populations of OTC-resistant bacteria, suggesting that raw materials and manufacturing processes may also impact the carriage of OTC-resistant bacteria in the fish feed (Granados-Chinchilla et al., 2014). The most common antimicrobial resistance documented in gram-negative bacteria was toward tetracycline 67\% (Granados-Chinchilla and Rodríguez, 2017), thus justifying that OTCresistance was common among the bacterial flora of the aquaculture environment. Also, earlier studies have shown the development of antibiotic-resistance in microbial populations of fish when antibiotics were used in aquaculture (McPhearson et al., 1991; Miranda and Zemelman, 2002a, b). Since the majority of the bacterial flora inhabit the fish gut (Hansen and Olafsen, 1999), examining the gut can shed light on the microbial population of the environment.

The Nile tilapia fries of the control group which has no exposure to antibiotics also yielded antibiotic-resistant bacteria but at lower levels than the OTC-dosed group. The levels of ORBCs in OX group were almost the same till day 10 post-dosing, which decreased significantly with days of culture. Evaluation of the distribution of resistant bacteria between control and OTC-dosed fish indicated that OTCdosing led to a change in the profile of gut bacterial flora. The OTC-dosing at the therapeutic level ( $80 \mathrm{mg} / \mathrm{kg}$ biomass/day) recorded a significant increase in ORBCs and their proportions in the TPCs $(0.02276 \%)$ on day 10 OTC-dosing, thus confirmed that antibiotic use lead to the development of antibiotic resistance in the Nile tilapia intestinal bacterial populations. The increase in ORBCs was 22 folds in the $1 \mathrm{X}$ group and 17 folds in $10 \mathrm{X}$ group compared to the levels on day 0 . The withdrawal of OTC-dosing decreased the levels of OTC-resistant bacterial population. Though the OTC-resistant bacterial population increased in the $10 \mathrm{X}$-dosed group, the increment was significantly lower than the $1 \mathrm{X}$ group. The resistant bacterial population though reduced with time in OTC-dosed groups, it never reached the level of the control group on day 42 post-OTC-dosing. On day 42 post-OTCdosing, ORBCs populations were almost 37.5 folds in the $1 \mathrm{X}$ group and 16.90 folds in $10 \mathrm{X}$ group higher than in the control group. It could, possibly, be due to the bactericidal effect of OTC on the susceptible bacterial population at the highest concentration. The results of Mannan et al. (2020) also suggested that antibiotic treatment can eradicate susceptible microorganisms. Also, the bactericidal effect was not sufficient enough to reduce the OTCresistant bacterial populations and the release of these bacteria along with faeces may spread their population in the aquaculture environment, which is a serious cause for concern. The results corroborate earlier studies (DePaola et al., 1995; Mannan et al., 2020), who documented a reduced percentage of resistant bacterial counts after cessation of medication.

Chloramphenicol-resistant bacteria: Alike the ORBCs, the CRBCs of the control group fluctuated from $3.08 \pm 0.03$ to $4.21 \pm 0.01 \log _{10}$ $\mathrm{cfu} / \mathrm{g}$. It indicated that substantial numbers of intestinal bacterial populations $(0.000072$ to $0.000404 \%$ ) were resistant to chloramphenicol. In aquaculture systems, the bacterial resistence to chloramphenicol and OTC are common (DePaola et al., 1995; Singh et al., 2009; Abraham, 2011). The results on the quantitative 
distribution of CRBCs in OTC-dosed $O$. niloticus fries for 10 consecutive days demonstrated a level of $5.56 \pm 0.05$ and $5.49 \pm 0.02 \log _{10} \mathrm{cfu} / \mathrm{g}$ in $1 \mathrm{X}$ and $10 \mathrm{X}$ groups, respectively. The contribution of CRBCs in the TPCs were $0.016053 \%$ and $0.006208 \%$, respectively in $1 \mathrm{X}$ and $10 \mathrm{X}$ groups on day 10 OTC-dosing compared to $0.000072 \%$ in control. The increase in CRBCs was 195 folds in the $1 \mathrm{X}$ group and 75 folds in 10X group compared to levels of day 0 . These results suggested that OTC-dosing not only increased the OTC-resistance but also the chloramphenicol-resistance in the intestinal flora of Nile tilapia. The highest proportion of chloramphenicol-resistance was noted on day 10 OTC-dosing in the $1 \mathrm{X}$ group. Although the bacterial resistance to OTC and chloramphenicol is plasmid-mediated (FAO/ OIE/WHO, 2006), the levels of intestinal chloramphenicol-resistant bacteria in Nile tilapia was significantly low compared to OTCresistant bacteria as observed in an earlier study (Ezung and Abraham, 2013). Though the levels of CRBCs decreased with the withdrawal of OTC-dosing, their levels were significantly higher than the control at the end of the experiment. On day 42 post-OTC-dosing, The CRBCs populations were almost 70 folds in the $1 \mathrm{X}$ group and 55 folds higher in $10 \mathrm{X}$ group than in control. These results further advocated that OTC-dosing may lead to cross-resistance, which may complicate the antibiotic therapy in

\section{REFERENCES}

Abraham TJ and Bardhan A, 2019. Emergence and spread of antimicrobial resistance in motile aeromonads of the aquaculture environment. Indian J Anim Hlth, 58(2-SPL): 39-52, doi: 10.36062/ijah. 58.2SPL.2019.39-52

Abraham TJ, 2011. Food safety hazards related to emerging antibiotic-resistant bacteria in cultured freshwater fish of Kolkata, India. Adv J Food Sci Technol, 3(1): 69-72 aquaculture. The pooled observations also suggested significantly higher levels of both ORBCs and CRBCs in the oral OTC-dosed monosex Nile tilapia at the therapeutic dose.

The present study used a controlled laboratory setup to test the influence of OTC on the intestinal microflora dynamics of Nile tilapia fry. In general, the OTC-dosing for 10 consecutive days had no significant effect on the levels of intestinal TPCs of Nile tilapia fries, but it led to a change in the resistance profile of the intestinal bacterial flora. The OTC-dosing not only increased the OTC-resistance but also favoured cross-resistance to chloramphenicol among the intestinal bacterial flora of Nile tilapia fries. The release of these resistant bacterial population and their spread in the aquaculture environment are a serious cause for concern. This calls for an urgent need for the judicious use of antibiotics to control the bacterial diseases in aquaculture.

\section{ACKNOWLEDGEMENTS}

The research work was supported by the Indian Council of Agricultural Research, Government of India, New Delhi under the All India Network Project on Fish Health (Grant F. No. CIBA/ AINP-FH/2015-16 dated 02.06.2015). The authors thank the Vice-Chancellor, West Bengal University of Animal and Fishery Sciences, Kolkata for providing necessary infrastructure facility to carry out the work.

Adeoye AA, Jaramillo-Torres A, Fox SW, Merrifield DL and Davies SJ, 2016. Supplementation of formulated diets for tilapia (Oreochromis niloticus) with selected exogenous enzymes: overall performance and effects on intestinal histology and microbiota. Anim Feed Sci Technol, 215: 133-143, doi: 10.1016/ j.anifeedsci.2016.03.002

Almeida AR, Tacão M, Machado AL, Golovko O, 
Zlabek V et al., 2019. Long-term effects of oxytetracycline exposure in zebrafish: A multilevel perspective. Chemosphere, 222: 333-344, doi: 10.1016/j.chemosphere. 2019.01.147

APHA, 1992. Standard methods for the examination of water and waste water. $18^{\text {th }}$ edn., American Public Health Association, Washington DC, pp986-9-87

Burridge L, Weis JS, Cabello F, Pizarro J and Bostick K, 2010. Chemical use in salmon aquaculture: A review of current practices and possible environmental effects. Aquaculture, 306(1-4): 7-23, doi: 10.1016/j.aquaculture.2010.05.020

Chowdhury MBR, Muniruzzaman M and Uddin MN, 1989. Study on the intestinal bacterial flora of tilapia Oreochromis niloticus. Bangladesh J Aquac, 11: 65-70

DePaola A, Peeler JT and Rodrick GE, 1995. Effect of oxytetracycline- medicated feed on antibiotic resistance of gram-negative bacteria in catfish ponds. Appl Environ Microbiol, 61: 2335-2340, doi: 10.1128/AEM.61.6.2335-2340.1995

El-Sayed A-FM, 2013. Tilapia feed management practices in sub-Saharan Africa. In: On-farm feeding and feed management in -aquaculture. (Hasan MR, New MB, eds). FAO Fisheries and Aquaculture Technical Paper No. 583. FAO, Rome, pp377-405, http://www.fao.org/tempref/ FI/CDrom/T583/root/14.pdf [13 Jan 2020]

Ezung R and Abraham TJ, 2013. Sensory and microbial quality of retail finfish with emphasis on antibiotic-resistant bacteria. J Aquat Food Prod Technol, 22(5): 474-486, doi: 10.1080/ 10498850.2012.666711

Fan L, Chen J, Meng S, Song C, Qiu L et al., 2015. Characterization of microbial communities in intensive GIFT tilapia (Oreochromis niloticus) pond systems during the peak period of breeding. Aquac Res, 48(2): 459-472, doi: 10.1111/are.12894

FAO/OIE/WHO, 2006. Report of a Joint Expert Consultation on Antimicrobial Use in Aquaculture and Antimicrobial Resistance: Seoul, Republic of Korea, 13-16 June 2006. WHO, Geneva, Switzerland, pp97, https:// apps.who.int/iris/handle/10665/133869
Giatsis C, Sipkema D, Smidt H, Heilig H, Benvenuti G et al., 2015. The impact of rearing environment on the development of gut microbiota in tilapia larvae. Sci Rep, 5: 18206, doi: 10.1038/ srep 18206

Giatsis C, Sipkema D, Smidt H, Verreth J and Verdegem M, 2014. The colonization dynamics of the gut microbiota in tilapia larvae. PLoS ONE, 9: e103641, doi: 10.1371/journal.pone.0103641

Granados-Chinchilla F and Rodríguez C, 2017. Tetracyclines in food and feeding stuffs: from regulation to analytical methods, bacterial resistance, and environmental and health implications. J Anal Methods Chem, 2017: 1315497, doi: 10.1155/2017/1315497

Granados-Chinchilla F, Alfaro M, Chavarría G and Rodríguez C, 2014. Unravelling a vicious circle: animal feed marketed in Costa Rica contains irregular concentrations of tetracyclines and abundant oxytetracycline-resistant grampositive bacteria. Food Addit Contam Part A, 31(6): 1017-1025, doi: 10.1080/19440049. 2014.907504

Hansen GH and Olafsen JA, 1999. Bacterial interactions in early life stages of marine coldwater fish. Microb Ecol, 38(1): 1-26, doi: $10.1007 / \mathrm{s} 002489900158$

Hernandez SP, 2005. Responsible use of antimicrobials in aquaculture. FAO Fisheries Technical Paper No. 469, FAO, Rome, pp97

Husevåg B, Lunestad BT, Johannessen PJ, Enger $\varnothing$ and Samuelsen OB, 1991. Simultaneous occurrence of Vibrio salmonicida and antibioticresistant bacteria in sediments at abandoned aquaculture sites. J Fish Dis, 14: 631-640, doi: 10.1111/j.1365-2761.1991. tb00621.x

Huss HH, Ababouch L and Gram L, 2003. Assessment and management of seafood safety and quality. FAO Fisheries Technical Paper No. 444, FAO, Rome, pp230

Islam MJ, Liza AA, Reza AHMM, Reza MS, Khan MNA et al., 2014. Source identification and entry pathways of banned antibiotics nitrofuran and chloramphenicol in shrimp value chain of Bangladesh. Eur Asian J BioSci, 8: 71-83, doi: 10.5053/ejobios. 2014.8.0.7 
Jansen MD, Dong HT and Mohan CV, 2018. Tilapia lake virus: a threat to the global tilapia industry?. Rev Aquac, 11(3): 725-73, doi: 10.1111/ raq. 12254

Jerbi MA, Ouanes Z, Besbes R, Achour L and Kacem A, 2011. Single and combined genotoxic and cytotoxic effects of two xenobiotics widely used in intensive aquaculture. Mutat Res, 724: 2227, doi: 10.1016/j.mrgentox.2011.04.010

Julinta RB, Abraham TJ, Roy A, Singha J, Dash G et al., 2019. Effect of oxytetracycline-dosing on the growth, safety and intestinal histology of Nile tilapia, Oreochromis niloticus (L.) juveniles. Int J Curr Microbiol App Sci, 8(8): 2708-2724, doi: 10.20546/ijcmas.2019. 808.313

Mandal SC, Hasan M, Rahman MS, Manik MH, Mahmud ZH et al., 2009. Coliform bacteria in Nile tilapia, Oreochromis niloticus of shrimpGher, pond and fish market. World J Fish Mar Sci, 1(3): 160-166

Mannan M, Islam SR, Osman MH, Rahman MK, Uddin MN et al., 2020. Antibacterial activity of oxytetracycline on microbial ecology of Nile tilapia (Oreochromis niloticus) gastrointestinal tract under laboratory condition. Aquac Res, 51(5): 2125-2133, doi: 10.1111/are.14563

McPhearson RM, DePaola A, Zywno SR, Motes Jr, ML and Guarino AM, 1991. Antibiotic resistance in Gram-negative bacteria from cultured catfish and aquaculture ponds. Aquaculture, 99(3-4): 203211, doi: 10.1016/0044-8486(91)90241-X

Miranda CD and Zemelman R, 2002a. Bacterial resistance to oxytetracycline in Chilean salmon farming. Aquaculture, 212(1-4): 31-47, doi: 10.1016/S0044-8486(02)00124-2

Miranda CD and Zemelman R, 2002b. Antimicrobial multiresistance in bacteria isolated from freshwater Chilean salmon farms. Sci Total
Environ, 293(1-3): 207-218, doi: 10.1016/ s0048-9697(02)00022-0

Nayak SK, 2010. Role of gastrointestinal microbiota in fish. Aquac Res, 41(11): 1553-1573, doi: 10.1111/j.1365-2109.2010. 02546.x

Parata L, Mazumder D, Sammut J and Egan S, 2020. Diet type influences the gut microbiome and nutrient assimilation of genetically improved farmed tilapia (Oreochromis niloticus). PLoS One, 15(8): e0237775, doi: 10.1371/journal.pone.0237775

Romero J, Feijoo CG and Navarrete P, 2012. Antibiotics in aquaculture - use, abuse and alternatives. In: Health and environment in aquaculture (Carvalho E, David GS, Silva RJ, eds). InTech, pp159-199, http://www.intechopen.com/books/health-andenvironment-inaquaculture/antibiotics-inaquaculture-use-abuse-and-alternatives [5 Oct 2020]

Singh AK, Rathore G, Singh V, Mani I, Singh RK et al., 2009. Bacterial resistance to oxytetracycline in different life stages of Indian freshwater carp aquaculture system. Int J Microbiol Res, 1(1): 25-34, doi: 10.9735/ 0975-5276.1.1.25-34

Uddin MN and Al-Harbi AH, 2004. Seasonal variation of bacterial ponds in Saudi Arabia used for tilapia aquaculture. J Appl Aquacult, 16(1-2): 53-61, doi: 10.1300/J028v16n01_04

USFWS, 2015. Approved Drugs for Use in Aquaculture. Second edn., U.S. Fish and Wildlife Service's Aquatic Animal Drug Approval Partnership Program, American Fisheries Society's Fish Culture and Fish Health Sections, Association of Fish and Wildlife Agencies, and Fisheries and Water Resources Policy Committee's Drug Approval Working Group

Watts JEM, Schreier HJ, Lanska L and Hale MS, 2017. The rising tide of antimicrobial resistance in aquaculture: sources, sinks and solutions. Mar Drugs, 15(6): 158, doi: 10.3390/md15060158 